\title{
KAJIAN NORMATIF PERANAN NEGARA TERHADAP TINDAK PIDANA KEKERASAN DALAM RUMAH TANGGA
}

\author{
Oleh : \\ Suzanalisa *
}

\begin{abstract}
ABSTRAK
Karya Ilmiah ini mengandung penjelasan aspek tindak pidana kekerasan dalam rumah tangga yang memenuhi ciri-ciri penderitaan yang dialami oleh korban dan perbuatan yang dilakukan pelaku telah ditetapkan menurut hukum yang dilaksanakan, hakhak yang diperoleh korban kekerasan dalam rumah tangga yang telah ditetapkan menurut hukum yang dilaksanakan dalam memberikan rasa aman dan percaya diri untuk tidak takut dalam proses pembuktian pada sistem peradilan pidana. Tujuan perundangan yang lebih berat terhadap kasus kekerasan dalam rumah tangga sebagai perlindungan masyarakat dalam kuasa pencegahan tindak pidana yang berlaku, memperbaiki perilaku pelaku dan sebagai wujud peranan Pemerintah Indonesia terhadap warganegara dalam menjaga keamanan dan keharmonian. Peranan negara dalam sistem peradilan tindak pidana kekerasan dalam rumah tangga yang penting disebabkan tindak pidana kekerasan dalam rumah tangga mengganggu hak asasi manusia sebagai warganegara, mengancam ketenteraman umum, keselamatan negara dan tindakan negara dalam memberikan perlindungan dan pencegahan terhadap pelanggaran hak asasi manusia akibat dari kekerasan dalam rumah tangga yang dialami oleh korban.
\end{abstract}

Kata Kunci: KDRT, Pelaku, Korban, Perlindungan

\section{A. Aspek-aspek Tindak Pidana Kekerasan Dalam Rumah Tangga}

Kekerasan fisik yang dilakukan suami terhadap istri adalah suatu tindakan yang tidak wajar karena tindakan ini adalah punca utama kerusakan rumah tangga, di mana pelakunya merupakan ketua rumah tangga yang seperlunya melindungi keluarga. Namun sebaliknya tindakan yang mencederakan fisik, psikologi dan melakukan kekerasan terhadap istri ${ }^{1}$, tidak memperlihatkan lagi peranan sebagai kepala keluarga untuk saling membantu satu sama lain dalam penjagaan dan pendidikan anak. ${ }^{2}$ Kekerasan fisik yang dilakukan pelaku terhadap korban berupa memukul, menendang, menginjak, menampar sambil mencekik, melempar barang ke badan korban, melukai dengan tangan kosong atau alat dan membunuh. ${ }^{3}$

\footnotetext{
* Pengajar Program Magister Ilmu Hukum Unbari.

1 St. Zubaidah. 2013. Tinjauan Kriminologi Terhadap Kekerasan Dalam Rumah Tangga (Aspek Perundangan dan Sosiologis). Varia Peradilan Nomor 335 Oktober 2013. hal 104

${ }^{2}$ Talcott Parson, Robert F. 1955. Socialization and Interaction Process. Gleneoe. The Free Press. hal 23

3 E. Kristi Poerwandari. 2000. Pemahaman Bentuk Kekerasan Terhadap Wanita dan Alternatif Pemecahannya. Jakarta. Pusat Kajian Wanita dan Jender. Universitas Indonesia. hal 11
} 
Tindakan pelaku kekerasan dalam rumah tangga merupakan bentuk salah laku seseorang yang termasuk kategori tekanan fisik dari dalam (individual deviation) dan hasil tekanan dari suatu keadaaan (situational deviation). ${ }^{4}$ Tindakan pelaku kekerasan ini mengakibatkan kerugian korban dan menimbulkan reaksi sosial daripada masyarakat dan melanggar hukum atau ketentuan yang diiktiraf secara umum, maka perbuatan ini dikategorikan sebagai Tindak pidana. Sehingga jika dikaitkan dengan kekerasan dalam rumah tangga yang dilakukan oleh suami terhadap istri yang menimbulkan kerugian terhadap korban dan bertentangan dengan hukum yang dilihat dari perspektif tindak pidana, maka kekerasan merupakan tindak pidana.

Dari uraian di atas, dapatlah dilihat bahwa kekerasan dalam rumah tangga mengandungi ciri-ciri dari definisi tentang tindak pidana yang disimpulkan sebagai berikut: 1. penderitaan yang tidak menyenangkan dialami oleh korban kekerasan dalam rumah tangga (istri) pengenaan penderitaan yang disengajakan oleh pelaku (suami) terhadap korban (istri), di mana kedudukan suami merupakan ketua rumah tangga yang mempunyai bidang kuasa dan kuasa dalam rumah tangga

2. Perbuatan yang dilakukan oleh pelaku kekerasan dalam rumah tangga (suami) telah ditetapkan menurut hukum yang berlaku. ${ }^{5}$

Mengenai tindak pidana kekerasan dalam rumah tangga yang banyak dilakukan oleh suami terhadap istri, didapati lebih banyak berupa kekerasan fisik sebagaimana batasan kajian penyelidik. Ternyata pengertian ini dalam Undang Undang Nomor 23 Tahun 2004 tentang Penghapusan Kekerasan Dalam Rumah Tangga tidak dijumpai pengertian perundangan dari rasa sakit, jatuh sakit dan luka berat. Walhal pengertian merupakan perkara paling penting untuk menentukan dan membuktikan jenis perbuatan yang dilakukan oleh pelaku. Maka disebabkan itu pengertian tersebut perlu dicari dalam hukum pidana dan perundangan sehingga dapat dijelaskan sebagai berikut :

1. Rasa sakit merupakan kekerasan yang dialami seseorang tanpa ada kesan pada bentuk badan, contohnya menampar, memukul.

2. Jatuh sakit merupakan kekerasan yang dialami seseorang mengakibatkan adanya gangguan terhadap aktiviti tubuh manusia.

\footnotetext{
4 .M. Lemert. 2009. Kajian Kritis dan Analitis Terhadap Dimensi Teori - Teori Kriminologi Dalam Persfektif Ilmu Pengetahuan Hukum pidana Modern Ed Lilik Mulyadi. Malang. PN Kepanjen. hal 15

${ }^{5}$ Muladi, Ed. Muladi Dan Barda Nawawi Arief. 1992. Teori - Teori dan Bidang kuasa Tindak pidana, Bidangkuasa Pencegahan Tindak pidana dengan Undang - Undang Tindak pidana. Bandung . Alumni. hal 4
} 
3. Luka berat merupakan luka yang dialami seseorang di mana kriteria luka tersebut tergolong luka berat dalam Kasus 90 Kitab Hukum Hukum Pidana yaitu luka atau jatuh sakit yang tidak mungkin sembuh, tidak boleh menjalankan pekerjaan seharihari, kehilangan satu atau lebih fungsi panca indera, mendapat cacat berat, gugur atau matinya kandungan wanita ${ }^{6}$.

Kekerasan dalam rumah tangga merupakan masalah serius, selain memberi kesan kepada keharmonian dan keutuhan rumah tangga dan menjadikan rumah tangga sebagai neraka, ia juga dapat menimbulkan kesan psikologi kepada korban. Selain itu, kesan lain kekerasan dalam rumah tangga ialah mampu menjadi pencetus tindak pidana lain dalam masyarakat akibat dari kecenderungan suatu kekerasan. Kebanyakan korban adalah wanita (istri) dan pelaku adalah lelaki (suami), kedua-duanya rata-rata mempunyai ciri-ciri tipikal yang sama untuk berisiko menjadi korban dan pelaku dalam kekerasan dalam rumah tangga.

Adapun ciri-ciri tipikal yang membolehkan seseorang menjadi korban kekerasan dalam rumah tangga adalah mempunyai rasa percaya diri yang rendah dan cenderung pasrah, mengalah, memaklumi terhadap kekerasan yang dialami, mempunyai pemahaman dalam erti sempit bahwa keutuhan rumah tangga lebih diutamakan, kekerasan yang dialami merupakan penyebab dari diri sendiri sehingga merasa bertanggungjawab terhadap perilaku suami, mengalami permasalahan fisik seperti sakit kepala serta gangguan pencernaan, menggunakan seks sebagai jalan perdamaian dengan suami dan meyakini bahwa orang lain tidak akan mampu memberi pertolongan karena ini masalah dalaman dalam rumah tangga. Ciri-ciri tipikal menjadi pelaku kekerasan dalam rumah tangga adalah mempunyai sikap berkuasa, egois dalam rumah tangga, mempunyai pemahaman bahwa lelaki adalah pemimpin sehingga dapat menguasai istrinya atau dengan kata lain bahwa lelaki adalah kaum yang unggul dan wanita pula kaum inferior, menyalahkan orang lain sebagai pencetus kasusalahannya, mempunyai kecemburuan yang berlebihan sehingga mudah curiga, tampil dengan "kecelaruan personaliti", menjadikan stres sebagai alasan untuk menguasai istrinya, mengunakan seks sebagai bentuk pencerobohan yang sering kali digunakan untuk mengatasi ketidakberdayaannya, menderita kekerasan di masa kecilnya, tidak percaya bahwa perilakunya mengandungi akibat. ${ }^{7}$

\footnotetext{
${ }^{6}$ Guse Prayudi. 2011. Berbagai Aspek Tindak pidana Kekerasan Dalam Rumah Tangga. Yogyakarta. Merkid Press. hal 34

7 Moerti Hadiati Soeroso. 2010. Kekerasan Dalam Rumah Tangga Dalam Perspektif PerundanganViktimologis. Jakarta. Sinar Grafika . hal 85
} 
Pelaku kekerasan dalam rumah tangga dapat dibahagi kepada 3 ciri yaitu:

1. Emosi Agresif, ertinya pelaku ini mempunyai kebergantungan terhadap kewujudan pasangannya. Pada dirinya telah terasuh suatu pola peningkatan emosi yang diikuti dengan tindakan agresif terhadap pasangan. Bila pelaku mengawali dengan kekerasan psikologi, kekerasan tersebut dapat diteruskan pada kekerasan fisik yang berat.

2. Terlalu mengawal, pelaku ini telah terbentuk pola kawalan yang lebih mengarah kepada kawalan psikologi daripada kekerasan fisik.

3. Tidak menyesal, ertinya pelaku ini tidak terbentuk hubungan emosi atau rasa penyesalan terhadap kekerasan yang dilakukan kepada korban ${ }^{8}$

Pada realitinya kekerasan dalam rumah tangga mengandungi norma hukum pidana, tetapi terdapat beberapa perkembangan dari tindak pidana yang sudah selaras dengan kekerasan fisik yang dialami korban kekerasan dalam rumah tangga yaitu wanita (istri), adapun bentuk kekerasan yang dialami terbahagi kepada empat bentuk yaitu:

1. Kekerasan fisik biasa, merupakan perbuatan yang menimbulkan rasa sakit pada korban yang berlaku dalam rumah tangga dengan tidak menimbulkan kesan pada bentuk badan, contohnya mencubit, menampar, memukul. ${ }^{9}$

2. kekerasan fisik ringan, merupakan perbuatan yang menimbulkan rasa sakit pada korban (istri) yaitu korban merasa sakit tanpa ada kesan pada bentuk badan seperti tindakan menendang, tetapi korban tidak mengalami perubahan pada fisik namun perbuatan ini menimbulkan kasusakitan kepada korban (istri) seperti lebam pada lokasi tendangan. Akibat lebam tersebut korban masih boleh menjalankan aktiviti sehari-hari sebagaimana biasanya. ${ }^{\mathbf{1 0}}$

3. Kekerasan fisik mengakibatkan korban jatuh sakit atau luka berat, merupakan perbuatan yang mengakibatkan adanya gangguan terhadap aktiviti tubuh manusia, fungsi organ-organ dalam badan manusia atau luka berat. ${ }^{11}$ Contoh: kekerasan suami terhadap istri berupa melakukan percobaan pembunuhan yang bermula dengan pukulan dengan benda keras kepada istri sehingga istri mengalami kecederaan berat, pengsan sehingga istri tersebut tidak mampu menjalankan tugas sehari-hari. ${ }^{12}$

\footnotetext{
${ }^{8}$ Core Group. 2008. Modul Konseling kepada Pelaku Kekerasan Dalam Rumah Tangga. Jakarta. Mitra Wanita Workshop. hal 7

${ }^{9}$ Guse Prayudi. 2011. Opcit. hal 38

${ }^{10}$ Guse Prayudi. 2011. Opcit.. hal 45

${ }^{11}$ Guse Prayudi. 2011. Opcit.. hal 49

${ }^{12}$ St. Zubaidah. 2013. Opcit. hal 108
} 
4. Kekerasan fisik menyebabkan kematian korban merupakan perbuatan yang dilakukan oleh pelaku dalam lingkup rumah tangga penyebab kehilangan nyawa korban selepas munculnya rasa sakit, jatuh sakit dan luka berat. ${ }^{13}$ Contohnya kekerasan fisik yang berulang kali oleh pelaku kekerasan dalam rumah tangga dalam bentuk pukulan, tendangan kepada pelaku penyebab korban tidak berdaya akibat rasa sakit, luka berat, menimbulkan kelumpuhan fungsi alat-alat tubuh sehingga akhirnya korban meninggal dunia.

Kekerasan dalam rumah tangga menyebabkan berlakunya tindak pidana, dan tindak balas sosial masyarakat, justeru perlunya kepada suatu ilmu pengetahuan khusus yaitu kriminologi $1^{14}$. Hal ini disebabkan tindak pidana pada umumnya mempunyai dimensi yang luas dalam menganalisa masalah tindak pidana kekerasan dalam rumah tangga yaitu yang pertama, menjelaskan tindak pidana dipandang dari segi struktur sosial dan kesannya. Kedua, menjelaskan mengapa seseorang (suami) melakukan tindak pidana kekerasan dalam rumah tangga atau mengapa dalam masyarakat terdapat orang-orang yang melakukan tindak pidana dan terdapat pula sekumpulan orang atau orang-orang tertentu yang tidak melakukan tindak pidana. Ketiga, menjelaskan struktur sosial dan juga menjelaskan bagaimana seseorang atau sekumpulan orang menjadi penjahat. ${ }^{15}$

Suatu perbuatan yang telah memenuhi unsur-unsur tindak pidana perlu diberi perhatian serius, maksudnya diperlukan usaha-usaha pencegahan sebelum berlakunya tindak pidana dan pencegahan selepas berlakunya tindak pidana. Usaha ini mampu dicapai melalui saling kebergantungan antara politik hukum dan dasar tindak pidana yang digunakan dalam membanteras tindak pidana seperti melalui pelaksanaan peraturan perundangan penjara oleh suatu sistem keadilan tindak pidana (criminal justice sistem) yang dibentuk oleh negara dan usaha-usaha sosial, seperti dalam bidang pendidikan, peningkatan taraf hidup masyarakat, mengurangkan pengangguran, dan sebagainya. Tetapi hukum pidana masih dianggap menjadi panduan sebagai usaha untuk menekan kadar tindak pidana yang meresahkan masyarakat. ${ }^{16}$ Hukum pidana juga mampu berperanan sesuai dengan situasi dan keadaan melalui peraturan yang merupakan dasar negara yang

\footnotetext{
${ }^{13}$ Guse Prayudi. 2011. Opcit. hal 56

${ }^{14}$ Muhammad Mustafa. 1986. Kriminologi. Jakarta. Bina Aksara. hal 2-4

${ }^{15}$ Stephan Hurwitz. 1986. Kriminologi. Ed. Moeljatno. Jakarta. Bina Aksara. hal 2-4

16 Mardjono Reksodiputro. 2007. Hak Asasi Manusia Dalam Sistem keadilan tindak pidana Kumpulan Karangan Buku Ketiga. Jakarta. Universitas Indonesia. hal 92
} 
berguna untuk mengekspresikan norma-norma yang terkandung dalam masyarakat yang mempunyai tujuan akhir yaitu ketenteraman awam dan keselamatan masyarakat. ${ }^{17}$

Dengan demikian hukum pidana berarti bagaimana mengusahakan atau membuat dan merumuskan suatu perundangan penjara yang baik dinamakan asas hukum pidana. ${ }^{18}$ Secara mudahnya, asas hukum pidana merupakan asas pencegahan tindak pidana dengan hukum pidana. Penegakan hukum merupakan bahagian yang tak dapat dipisahkan dari dasar hukum pidana, politik tindak pidana, politik sosial yang mempunyai tujuan akhir mensejahterakan masyarakat, sehingga usaha pencegahan tindak pidana merupakan usaha penegakan hukum dalam rancangan pembangunan negara. ${ }^{19}$

\section{B. Hak-hak Korban Kekerasan dalam rumah tangga}

Perbuatan, kasusalahan dan pelanggaran yang dilakukan oleh pelaku kekerasan dalam rumah tangga (suami) yang berupa kekerasan fisik telah melanggar hak asasi manusia terhadap korban (istri). Hak asasi manusia wajib dihormati oleh sesiapa pun, karena hak asasi manusia merupakan hak dasar yang dimiliki manusia sejak lahir yang sangat berkaitan erat dengan kehormatan dan martabat manusia sebagai ciptaan Tuhan Yang Maha Esa. Pelanggaran hak asasi manusia yang dimiliki oleh seorang wanita telah banyak peraturannya dibicarakan dalam sistem hukum tentang hak asasi manusia baik diperingkat nasional, serantau dan antarabangsa.

Realiti di lapangan, korban kekerasan dalam rumah tangga tidak mau menjelaskan tindak pidana kekerasan dalam rumah tangga yang dialaminya. Hal ini disebabkan sikap korban atau keluarga korban sendiri berupa: korban menganggap bahwa keadaan yang dialaminya merupakan kasus yang biasa dalam rumah tangga dan hal ini bukan perbuatan tindak pidana, merasakan ia aspek peribadi dalaman dan berusaha untuk menutupi serta membela pelaku walaupun telah mengalami kekerasan. ${ }^{20}$ Korban menganggap bahwa keutuhan rumah tangga lebih penting, lebih-lebih lagi korban adalah suri rumah tangga dan apabila pelaku (suami) dikasuskan tindak pidana maka akan mengganggu hubungan rumah tangga dan anak-anak.

${ }^{17}$ Sudarto. 1981. Hukum dan Hukum pidana. Bandung. Alumni. hal 159

18 Barda Nawawi Arief. 1994. Beberapa Aspek Pengembangan Ilmu Hukum pidana Semarang. pidato pengukuhan guru besar hukum Undip. hal 29

11

${ }^{19}$ Muladi. 2002. Kapita Selekta Sistem keadilan tindak pidana. Semarang. BP, Universitas Diponegoro. hal

${ }^{20}$ Tapi Omas Ihromi, dkk. 2006. Penghapusan Diskriminasi Terhadap Wanita. Bandung. Alumni. hal 2 
Kekerasan dalam rumah tangga yang dialami oleh korban apabila diketahui oleh orang lain, dianggap oleh korban dan atau keluarga korban sebagai aib dan merendahkan harga diri. Korban beranggapan bahwa kekerasan yang dialaminya, apabila dilaporkan kepada agensi penegakan hukum akan menambah kerumitan dan penderitaan korban sebagai saksi kekerasan dalam rumah tangga yang dialami apabila korban telah meninggal dunia. $^{21}$

Kekerasan dalam rumah tangga yang dialami oleh korban sebenarnya adalah suatu keadaan yang tidak diingini, namun dari hubungan kehidupan sehari-hari, seseorang berpotensi menjadi korban apabila keadaan yang menyokong terjadinya kekerasan dalam rumah tangga wujud. Sehinggakan ke tahap korban akan sentiasa berjaga-jaga atau berwaspada terhadap kemungkinan berlaku tindak pidana kekerasan dalam rumah tangga. ${ }^{22}$

Sebenarnya semenjak korban mengalami kekerasan, korban secara mutlak mempunyai hak dan kewajiban yang perlu dihormati. Adapun hak korban yang dimaksudkan adalah mendapat ganti rugi atas penderitaan, sesuai dengan kemampuan pelaku. Ataupun sebaliknya jika menolak ganti rugi karena tidak memerlukannya, korban berhak mendapatkan ganti rugi untuk ahli warisnya bila korban meninggal dunia karena tindakan tersebut, mendapat bimbingan dan pemulihan, mendapatkan kembali hak miliknya, menolak menjadi saksi bila mana hal ini akan membahayakan dirinya, mendapat perlindungan dari ancaman pihak pelaku bila melapor dan menjadi saksi, mendapatkan bantuan Pengacara dan menggunakan kuasa hukum.

Adapun kewajiban korban adalah untuk tidak memutuskan tindakan hukum di tangan sendiri, berkolaborasi dengan masyarakat untuk mencegah berlakunya kasus yang berulang dan timbulnya korban yang lebih banyak menambah kewajiban korban untuk mencegah kehancuran si pelaku baik oleh diri sendiri, maupun oleh orang lain, ikut serta dalam bimbingan dan rehabilitasi pelaku, bersedia dibina atau membina diri sendiri agar tidak menjadi korban lagi, tidak menuntut ganti rugi yang tidak sesuai dengan kemampuan pelaku, memberi peluang kepada pelaku untuk memberi ganti rugi secara berperingkat atau sesuai kemampuannya, menjadi saksi bila tidak membahayakan diri sendiri dan

\footnotetext{
${ }^{21}$ G. Widiartana. 2009. Kekerasan Dalam Rumah Tangga Persfektif Perrayuanan Hukum. Yogyakarta. Universitas Atma Jaya. hal 2

${ }^{22}$ Sagung Putri, M.E.Purwani. 2008. Viktimisasi Tindak pidana terhadap Perempuan. Kerta Patrika. Vol. 33 Nomor 1 Januari 2008. hal 3
} 
mempunyai jaminan. Hak dan kewajiban korban yang telah diuraikan bergantung juga kepada korban perlindungan yang hendak diterima dan dijalankan. ${ }^{23}$

Hak-hak korban kekerasan dalam rumah tangga yang termaktub dalam Pasal 10, Undang Undang Nomor 23 Tahun 2004 tentang Penghapusan Kekerasan Dalam Rumah Tangga, menyebutkan :

Korban berhak mendapatkan :

a. Perlindungan dari pihak keluarga, Polisi, Penuntut Umum, pengadilan, Pengacara, badan sosial atau pihak lain baik sementara maupun berdasarkan penetapan perintah perlindungan dari pengadilan.

b. Perkhidmatan kesehatan sesuai dengan keperluan perobatan.

c. Pengendalian secara khusus berkaitan dengan kerahasiaan korban.

d. Pendampingan oleh pekerja sosial dan bantuan hukum pada setiap tahap proses perbicaraan sesuai dengan ketentuan peraturan perundangan.

e. Perkhidmatan bimbingan rohani.

Selain hak-hak korban yang termaktub dalam Pasal 10, hak-hak korban yang lain dapat dilihat dalam Pasal 26 Undang Undang Nomor 23 Tahun 2004 tentang Penghapusan Kekerasan Dalam Rumah Tangga yang menyebutkan :

a. Korban berhak melaporkan secara langsung kekerasan dalam rumah tangga kepada Polisi baik di tempat korban berada maupun di tempat kejadian kasus.

b. Korban dapat memberikan kuasa kepada keluarga atau orang lain untuk melaporkan kekerasan dalam rumah tangga kepada pihak Polisi baik di tempat korban berada maupun di tempat kejadian kasus.

Dengan adanya jaminan hak korban yang termaktub dalam ketentuan perundangan ini akan membuatkan para istri atau korban kekerasan dalam rumah tangga yang lain lebih berani melaporkan tentang kekerasan yang menimpanya. Hal ini karena seperti yang diketahui selama ini, kebanyakan korban kekerasan dalam rumah tangga tidak mempunyai keberanian untuk melaporkan peristiwa kekerasan yang menimpanya, sehingga dirinya terus menjadi korban kekerasan, bahkan perlakuan kekerasan tersebut boleh saja menjadi peristiwa rutin yang dialaminya setiap hari.

Adanya ketidakberanian korban kekerasan untuk melaporkan pelaku tindak pidana lebih banyak alasannya karena pertimbangan pelakunya adalah ahli dalam rumah

${ }^{23}$ Moerti Hadiati Soeroso. Opcit. hal 115 
tangga yang pada umumnya adalah kepala keluarga di mana korban menggantungkan keperluannya, baik keperluan lahir maupun keperluan batin.

Kekerasan dalam rumah tangga yang dialami oleh korban di dalam Undang Undang Nomor 23 Tahun 2004 tentang Penghapusan Kekerasan Dalam Rumah Tangga, sememangnya tidak dapat ditemui peraturan secara khusus mengenai kewajiban korban untuk melaporkan kekerasan. Meskipun begitu, adalah suatu kasus yang mustahil, jika ada hak tanpa diikuti oleh kewajiban.

Dalam Undang Undang tersebut pada Pasal 15 disebutkan kewajiban korban dan masyarakat lain sebagai berikut:

"Setiap orang yang mendengar, melihat atau mengetahui berlakunya kekerasan dalam rumah tangga wajib melakukan usaha-usaha sesuai dengan batas kemampuannya untuk:

a. Mencegah berlangsungnya tindak pidana.

b. Memberikan perlindungan kepada korban.

c. Membantu proses mengajukan permohonan penetapan perlindungan."

Melalui pernyataan dalam peruntukan Pasal 15 tersebut, dapat dibuat suatu kasusimpulan bahwa permasalahan berlakunya kekerasan dalam rumah tangga bukan hanya persoalan peribadi antara pelaku dan korban. Dengan kata lain tindak pidana kekerasan dalam rumah tangga bukan hanya menjadi urusan orang-orang yang ada dalam lingkup rumah tangga tersebut, atau bukan hanya permasalahan peribadi, namun telah menjadi kewajiban bersama, baik korban maupun orang lain atau masyarakat untuk mencegah berlakunya kekerasan dalam rumah tangga.

Terlibatnya orang lain atau masyarakat dalam persoalan ini, bukan merupakan satu bentuk campur tangan dalam urusan orang, tetapi sudah menjadi tanggungjawab dan kewajiban kepada siapa saja yang mendengar, mengetahui dan menyaksikan berlakunya kekerasan dalam rumah untuk mencegahnya dan melaporkannya kepada pihak berwajib agar dilakukan penegakan hukum terhadap permasalahan tersebut.

Perlindungan terhadap korban kekerasan dalam rumah tangga ini menjadi sangat penting supaya dapat memberikan rasa aman dan percaya diri korban berupa dorongan, motivasi untuk tidak takut dalam proses pembuktian pada sistem kehakiman tindak pidana, selanjutnya memenuhi rasa keadilan dan sebagai mewujudkan perlindungan terhadap hak- 
hak jantina dari segala kekerasan, serta menyatakan bahwa kekerasan merupakan pelanggaran hak asasi manusia. ${ }^{24}$

Korban jangan hanya dijadikan sebagai penyokong pendedahan kebenaran suatu tindak pidana dan apabila pelaku dibuktikan bersalah maka korban telah cukup mendapat perlindungan hukum, ${ }^{25}$ namun korban kekerasan dalam rumah tangga berhak mendapatkan jaminan perlindungan dan penegakan hukum terhadap pelaku.

Penjelmaan advokasi terhadap korban kekerasan dalam rumah tangga dalam mendapatkan rasa aman bermaksud diperlukan kerjasama antara pihak keluarga korban, Pengacara, badan sosial, Polisi, pendakwaan, pengadilan, maupun pihak-pihak yang dapat dilibatkan ke atas peruntukan pengadilan sebagaimana termaktub dalam Undang Undang Nomor 23 Tahun 2004 tentang Penghapusan Kekerasan Dalam Rumah Tangga. Perlindungan yang diberikan kepada korban kekerasan dalam rumah tangga yaitu yang pertama, perlindungan sementara, maksudnya perlindungan yang diberikan oleh pihak Polisi/badan sosial kepada korban kekerasan dalam rumah tangga sampai ada penetapan perlindungan yang diperintahkan oleh pengadilan (Pasal 1 Undang Undang Nomor 23 Tahun 2004 tentang Penghapusan Kekerasan Dalam Rumah Tangga). Dan yang kedua, perintah perlindungan, maksudnya perintah perlindungan kepada korban kekerasan dalam rumah tangga berdasarkan penetapan pengadilan. ${ }^{26}$

Dalam realitinya prosedur perlindungan terhadap korban kekerasan saat ini hanya bersifat abstrak menurut hukum yang berlaku sedangkan perlindungan hukum menunggu bagaimana penerapan dan pelaksanaan hukum. ${ }^{27}$ Dalam amalan, korban hanya dijadikan sebagai saksi sehingga timbul kesan bahwa perlindungan terhadap hak korban terabai, yang dipengaruhi oleh faktor-faktor berupa :

1. Faktor hukum; Hukum merupakan sumber hukum utama dalam penegakan hukum untuk mewujudkan keamanan dan ketenteraman awam, namun hukum dalam perlindungan terhadap korban bersifat hubungan saja dan kewujudannya hanya pada tindak pidana tertentu saja.

2. Kesdaran hukum korban; Ketidakmauan korban kekerasan dalam rumah tangga untuk melaporkan derita yang dialami dengan menganggap bahwa tindak pidana yang

\footnotetext{
${ }^{24}$ Aditya Amanda Rahmat. 2013. Kajian Hukum Tentang kekerasan Seksual Yang Dilakukan Oleh Suami Terhadap Istri Berdasarkan Undang Undang Nomor 23 Tahun 2004 tentang Penghapusan Kekerasan Dalam Rumah Tangga. Karya Ilmiah Penerbit Fakultas Hukum Universitas Mataram. hal 12

${ }^{25}$ Didik M. Arief Mansur \& Elisatris Gultom. Urgensi Perlindungan Korban Tindak pidana Antara Norma dan Realita. Jakarta. Raja Grafindo Persada. hal 38

${ }^{26}$ Guse Prayudi.Opcit. hal 122

${ }^{27}$ Moerti Hadiati Soeroso. Opcit. hal 120
} 
dialami merupakan aib, baik kepada diri sendiri maupun korban merupakan tindakan yang merugikan korban sendiri dan menimbulkan pandangan di masyarakat bahwa tindakan ini sebagai perbuatan biasa berlaku dalam sesebuah rumah tangga.

3. Kemudahan Penyokong; Penyelesaian dan prapenyelesaian dalam perlindungan korban kekerasan dalam rumah tangga yang kurang memadai. Hal ini karena tindak pidana ini dalam tahap pengendalian terhadap korban bermula dari membuat laporan perlu dibezakan daripada tindak pidana pada umumnya sehingga sangat diperlukan bilik perkhidmatan khusus yang selesa dan kelonggaran kepada korban untuk menyampaikan keterangan tentang penderitaan yang dialami. Bilik khas ini juga diperlukan oleh korban untuk merehatkan fisik dan psikologi, yang bermanfaat kepada korban kembali dalam proses pelaporan selanjutnya.

4. Sumber daya manusia; kurangnya sumber daya manusia baik dari segi kuantiti dan kualiti dalam pemberian perkhidmatan perlindungan terhadap korban kekerasan dalam rumah tangga, berupa kurangnya jumlah anggota Polisi wanita sebagai pegawai dalam perkhidmatan terhadap korban kekerasan dalam rumah tangga lebih banyak wanita dan kualiti anggota Polisi wanita dalam pemahaman secara psikologi dalam membina kembali kepercayaan diri korban tersebut agar mempunyai kekuasaan menjalani proses perbicaraan selanjutnya. ${ }^{28}$

Untuk itu pengendalian korban kekerasan dalam rumah tangga di masa hadapan perlu menjadi keutamaan bukan hanya digunakan sebagai penyokong, tetapi memberikan perlindungan hukum terhadap korban dengan meletakkan sebagai subjek hukum, yang mempunyai kedudukan yang sama di depan hukum dan dalam penegakan hukum terhadap tindak pidana yang dialami korban adalah berdasarkan belas kasihan dan hormat atas martabat korban. ${ }^{29}$

\section{Tujuan Hukuman Tindak pidana Kekerasan dalam rumah tangga}

Hukuman tindak pidana terhadap pelaku kekerasan dalam rumah tangga dilakukan atas adanya perbuatan dan kasusalahan. Perbuatan dan kasusalahan ini merupakan idea konsep asas penghukuman tindak pidana. Hal ini menjadikan dua asas fundamental yang berkaitan dengan pemberian hukuman tindak pidana yaitu asas perundangan dan asas kasusalahan. Asas perundangan menyangkut perbuatan yang

${ }^{28}$ Didik M. Arief Mansur \& Elisatris Gultom. Opcit. hal 173-179

${ }^{29}$ Didik M. Arief Mansur \& Elisatris Gultom. Opcit. hal 31 
dilakukan oleh pelaku kekerasan dalam rumah tangga yang meresahkan masyarakat sebagai asas kemasyarakatan, dan asas kebersalahan/kasusalahan melibatkan orang yang melakukan (pelaku kekerasan dalam rumah tangga) sebagai asas kemanusiaan/ individu dan bila digabungkan kedua-dua asas ini disebut asas kesimbangan. Asas-asas ini perlu menjadi perhatian dalam menjatuhkan hukuman tindak pidana terutama hakim. ${ }^{30}$

Istilah "perundangan" dapat disempitkan ertinya yaitu perundangan dalam kasus tindak pidana yang bersinonim dengan "tindak pidana" atau "pemberian/penghukuman tindak pidana" oleh hakim. Hukuman ialah penderitaan yang sengaja dibebankan kepada orang yang melakukan perbuatan yang memenuhi syarat-syarat tertentu ${ }^{31}$. Selanjutnya hukuman adalah reaksi terhadap tindak pidana dan mewujudkan suatu kesdihan yang sengaja ditimpakan negara kepada pembuat tindak pidana itu. Kesdihan ini bukanlah suatu tujuan yang terakhir dicita-citakan masyarakat. ${ }^{32}$ Begitupula Hukum pidana merupakan satu perundangan "disatu segi merupakan pencegahan, yaitu sebagai pencegahan tindak pidana, di lain segi merupakan pula penentuan hukum, merupakan koreksi dan reaksi atas suatu yang tidak mematuhi hukum, yang juga tidak merupakan pembalasan". ${ }^{3}$

Sehingga yang penting diperhatikan dalam memanfaat hukum pidana dalam menangani tindak pidana kekerasan dalam rumah tangga yaitu : harapan dijadikan hukuman tindak pidana sebagai tempat melepaskan kemarahan sebagai wujud pembalasan dendam terhadap tindakan kekerasan yang telah dilakukan oleh pelaku, perlu jelas kerugian yang dialami oleh korban sebagai bukti untuk menghukum pelaku, jangan jadikan hukuman tindak pidana untuk mencapai tujuan yang ingin dicapai dengan kaedah lain yang lebih efektif dengan kerugian yang lebih sedikit, jangan jadikan hukuman tindak pidana sebagai hitungan kerugian yang lebih besar daripada kerugian ditimbulkan terhadap perancangan tindak pidana, jangan jadikan hukuman tindak pidana sebagai usaha sampingan sehingga menghasilkan kerugian lebih dengan perbuatan yang akan ditindak pidanakan, namun yang diharapkan melalui hukuman tindak pidana perlu rasional, menjaga kesimbangan, kesrasian, moral semua pihak, sebagai penyelesaian non penal dalam pencegahan kekerasan dalam rumah tangga. ${ }^{34}$

\footnotetext{
${ }^{30}$ Sudarto. 1986. Kapita Selecta Hukum Pidana. Bandung. Alumni. hal 72

${ }^{31}$ Sudarto. 1981. Hukum dan Hukum pidana. Alumni Bandung.hal 71-72

${ }^{32}$ Roeslan Saleh. 1983. Stelsel Tindak pidana Indonesia. Jakarta. Aksara Baru.hal 9

33 Roeslan Saleh. 1983. Suatu Reorientasi Dalam Undang Undangpidana. Jakarta. Cet. Kedua. Aksara Baru.hal 30-31

${ }^{34}$ G. Widiartama. 2009. Kekerasan Dalam Rumah Tangga (Persfektif Permohonan Hukum. Yogyakarta. Atmajaya. hal 52
} 
Hukuman tindak pidana yang dijatuhkan kepada pelaku mempunyai tujuannya. Ramai ahli hukum pidana memberikan pendapat tentang tujuan hukuman tindak pidana, menyatakan bahwa perundangan tindak pidana merupakan penjamin terbaik dari segala bentuk ancaman kebebasan manusia bila dilakukan secara teliti, cermat dan manusiawi. Perundangan juga jangan dilakukan secara sembarangan serta paksaan, karena akan mengakibatkan fungsinya boleh berubah dari sekatan tindak pidana sebaliknya menjadi pengancam. Senada dengan Barda Nawawi Arief menyatakan bahwa hubungan antara penetapan perundangan tindak pidana dan tujuan hukuman tindak pidana adalah titik penting dalam menentukan strategi perancangan politik tindak pidana. Menentukan tujuan hukuman tindak pidana dapat menjadi landasan untuk menentukan cara atau tindakan yang akan digunakan. Dasar menetapkan perundangan tindak pidana apa yang dianggap paling baik untuk mencapai matlamat, setidak-tidaknya mendekati tujuan, tidak terlepas dari persoalan pemilihan pelbagai alternatif sekatan. Masalah pemilihan pelbagai alternatif untuk memperoleh hukuman tindak pidana mana yang dianggap paling baik, paling tepat, paling patut, paling berjaya atau terlibatan merupakan masalah yang tidak mudah. ${ }^{35}$

Dari pendapat di atas, dapat disimpulkan bahwa hukuman tindak pidana mengandungi unsur-unsur atau ciri-ciri sebagai berikut:

1. Hukuman tindak pidana itu pada hakikatnya merupakan suatu pengenaan penderitaan atau kesdihan atau akibat lain yang tidak menyenangkan;

2. Hukuman tindak pidana itu diberikan dengan sengaja oleh orang atau badan yang mempunyai kekuasaan (oleh kekuasan yang berbidangkuasa);

3. Hukuman tindak pidana itu dikenakan kepada seseorang atau badan hukum (korporasi) yang telah melakukan tindak pidana menurut hukum.

Tujuan hukuman tindak pidana dijatuhkan telah menjadi wacana dalam kalangan pemikir, ahli akademik dan pengamal hukum sejak dahulu lagi. Dari berbagai wacana ilmiah tentang teori tujuan hukuman tindak pidana, pada prinsipnya dapat dikelompokkan menjadi 2 (dua) kelompok teori, yaitu Teori Absolut atau Teori Pembalasan dan Teori Relatif atau Teori Tujuan.

Setiap teori memiliki ciri-ciri utama seperti berikut :

\footnotetext{
35 Barda Nawawi Arief. 1992. Teori - Teori dan Bidang kuasa Tindak pidana, Bidangkuasa Pencegahan Tindak pidana dengan Undang - Undang Tindak pidana. Bandung . Alumni. hal 156
} 


\section{Peranan Negara Dalam Sistem Keadilan Tindak pidana Kekerasan dalam rumah tangga}

Warganegara merupakan kumpulan manusia yang menetap di suatu wilayah, bersama-sama memenuhi keperluan hidup sehari-hari, menghadapi bahaya, bencana, dan melanjutkan keturunan melalui hubungan sosial sehingga memerlukan suatu wadah untuk mencapai tujuan yang sama sehingga diperlukan pembentukan negara. ${ }^{36}$ Kemudian untuk memenuhi tujuan tersebut diperlukan seeorang atau kumpulan kecil yang diberikan hak, kuasa untuk mengatur dan memimpin ahli-ahlinya. Ahli perlu mentaati peraturan-peraturan yang telah ditentukan atas arahan pemimpin, yang pada akhirnya inilah yang disebut negara. ${ }^{37}$

Kekerasan fisik yang dialami oleh korban kekerasan dalam rumah tangga ini merupakan suatu tindak pidana. Tindak pidana yang ditimbulkan tentunya mengganggu keselesaan hak asasi setiap warga, ketenteraman awam dan keselamatan negara. Hal ini karena menimbulkan kerugian kepada korban (istri) juga memberi kesan terhadap perkembangan pertumbuhan anak, yang cenderung meniru tindakan ayahnya suka memukul ibu, sebagai tindakan wajar yang nantinya akan berpengaruh dalam lingkungan pergaulan anak tersebut. ${ }^{38}$ Ini karena keluarga merupakan wadah di mana anak-anak berinteraksi sebelum terjun ke dalam masyarakat. Bila mana ayah ibu berselisih faham sehingga berlakunya kekerasan, maka dinyatakan keluarga ini tidak harmoni. Keluarga yang tidak harmoni akan menularkan penyakit-penyakit yang menyimpang kepada ahli keluarga terutama anak, sehingga anak cenderung kepada perbuatan menyimpang dan ini merupakan indikator berlakunya tindak pidana. Dari uraian ini jelas kelihatan berlaku kegagalan penjagaan terhadap anak dalam keluarga karena dari unit terkecil yaitu keluarga telah timbulnya bibit tindak pidana. ${ }^{39}$

Kajian yang telah dilakukan membuktikan bahwa 50\% hingga $80 \%$ lelaki yang memukul istrinya ternyata dibesarkan dalam rumah tangga yang orang tuanya suka memukul dan melakukan kekerasan dalam rumah karena membesar dalam rumah tangga yang penuh kekerasan akan menjadikan orang yang kejam. ${ }^{40}$

\footnotetext{
${ }^{36}$ Saafroedin Bahar. 2002. Konteks Kenegaraan Hak Asasi Manusia. Jakarta. Sinar Harapan. hal 106

${ }^{37}$ C.S.T Kansil.2001. Ilmu Negara Rakyat dan Indonesia. Jakarta. PT. Pradnya Paramita. hal 133

${ }^{38}$ Rika Saraswati. 2009. Wanita dan Penyelesaian Kekerasan Dalam Rumah Tangga. Bandung. PT. Citra Adtya Bakti. hal 20-21

${ }^{39}$ G. Widiartana. 2009. Kekerasan Dalam Rumah Tangga Persfektif Permohonan Hukum. Yogyakarta. Universitas Atma Jaya. hal 1

${ }^{40}$ Ciciek Farha. 2008. Referensi kepada Hakim Peradilan Syariah tentang Kekerasan Dalam Rumah Tangga. Jakarta. Komnas Wanita. hal 35
} 
Dilihat dari bentuk kekerasan dalam rumah tangga yang berlaku terhadap korban, peranan negara menjadi sangat penting untuk menjelaskan tindak pidana ini dan memberikan sistem keadilan tindak pidana kekerasan dalam rumah tangga sejauh mana yang boleh. Negara merupakan pemegang kekuasaan tertinggi yang tidak diikat oleh organisasi lain, mempunyai kedaulatan, memaksa kekerasan fisik secara hukum untuk menjaga ketenteraman awam dalam masyarakat dan mempunyai hak monopoli yaitu kuasa untuk menetapkan pola peraturan perundangan mengenai semua warga negara. ${ }^{41}$

Pelanggaran hak asasi manusia akibat terjadinya kekerasan dalam rumah tangga perlu dilindungi oleh negara melalui tindakan oleh institusi-institusi pembentuk hukum dengan mengeluarkan peraturan perundangan tentang pemberian perlindungan terhadap hak asasi manusia. Pengakuan terhadap hak asasi manusia sesungguhnya merupakan hasil dari konsep negara hukum.

Ada empat unsur penting negara hukum, yaitu bahwa kerajaan (dalam erti luas) dalam melaksanakan tugas dan kewajibannya perlu berdasarkan atas hukum atau peraturan perundangan, adanya jaminan terhadap hak-hak asasi manusia (dan warga negara); adanya pembahagian kekuasaan dalam negara dan adanya pengawasan dari badan kehakiman. ${ }^{42}$

Oleh karena itu, pelaku kekerasan dalam rumah tangga perlu diberi perundangan, bahkan kalau boleh lebih berat perundangannya dari apa yang dilakukan oleh orang lain seperti tindak pidana dengan kekerasan fisik, di mana pelaku dan korban tidak saling kenal. Tujuannya agar penegakan hukum benar-benar dapat berjalan menurut yang sepatutnya, walaupun tindak pidana atau kekerasan itu dilakukan oleh ahli keluarga kepada ahli keluarga lain.

Sebagaimana diketahui, salah satu usaha dalam memberi perlindungan kepada warganegara adalah dengan pencegahan tindak pidana, baik sebelum berlaku mau pun setelah berlakunya perbuatan tindak pidana. Sebagaimana pendapat Mardjono Reksodiputro bahwa kuasa pencegahan tindak pidana boleh dilakukan melalui pelaksanaan peraturan perundangan tindak pidana oleh suatu sistem kehakiman tindak pidana yang dibentuk oleh negara. Disamping itu negara (masyarakat) dapat pula berusaha melalui usaha sosial, seperti dalam bidang pendidikan, peningkatan taraf hidup masyarakat, mengurangkan pengangguran dan lain sebagainya. Namun demikian, hukum pidana dalam

${ }^{41}$ C.S.T Kansil. 2001.Ilmu Negara Rakyat dan Indonesia. Jakarta. PT. Pradnya Paramita. hal 167

${ }^{42}$ Sri Sumantri M. 1992. Bunga Rampai Hukum Tata Negara. Bandung. Alumni. hal 29 
banyak hal masih dianggap sebagai landasan utama agar angka tindak pidana berada dalam batas toleransi masyarakat. ${ }^{43}$

Usaha kerajaan dalam memberi perlindungan kepada masyarakat dari perbuatan tindak pidana merupakan inti dari dasar tindak pidana yang merupakan bahagian yang integral dari usaha mencapai kesjahteraan masyarakat sebagai tujuan dasar sosial atau politik pembangunan.

Bentuk peranan negara dalam memberi perlindungan terhadap korban kekerasan dalam rumah tangga dalam pelanggaran hak asasi manusia yang berat, yang berhak ke atas perlindungan fisik dan mental dari ancaman, gangguan, kegerunan dan kekerasan dari pihak mana pun. ${ }^{44}$ Secara khusus perlindungan negara terhadap korban kekerasan dalam rumah tangga yang kebanyakannya ialah wanita adalah Undang Undang Nomor 23 Tahun 2004 tentang Penghapusan Kekerasan Dalam Rumah Tangga yang merupakan satu bentuk perlindungan untuk melindungi masyarakat yang mengalami kekerasan dalam rumah tangga dalam lingkup rumah tangga ${ }^{45}$ dan Undang Undang Nomor 1 Tahun 1974 tentang Perkawinan sebagai bentuk perlindungan negara terhadap institusi perkawinan.

Peranan negara untuk meminimalkan tindak pidana kekerasan dalam rumah tangga telah dilakukan bermula dari dasar pembentukan keluarga sebagaimana dinyatakan dalam Undang Undang perkawinan. Hukum keluarga sebagaimana termaktub dalam Undang Undang Perkawinan Nomor 1 Tahun 1974 tentang Perkawinan menurut dasar negara menyenaraikan suatu keluarga yang ideal, peranan dan tanggungjawab setiap anggotanya. Suami istri diwajibkan saling cinta mencintai, hormat menghormati, setia dan memberi bantuan lahir dan batin. Suami sebagai kepala keluarga yang melindungi istri dan memenuhi keperluan hidup berumah tangga, sementara istri sebagai ibu rumah tangga yang mengatur urusan rumah tangga. Selanjutnya ditentukan tentang hubungan orang tua dan anak yaitu orang tua memelihara dan mendidik anak-anak mereka dengan sebaikbaiknya dan seterusnya kewajiban anak menghormati orang tua dan mentaati nasihat orang tua yang membina terhadap anak mereka.

\footnotetext{
${ }^{43}$ Mardjono Reksodiputro. 2007. Opcit, hal 92

${ }^{44}$ Gatot Suparmo Nomor. 1993. Hukum Pembuktian di Peradilan Syariah. Bandung. Alumni. hal 1

${ }^{45}$ Nurnaningsih Amriani. 2013. Kekerasan Dalam Rumah Tangga dan Hak Asasi Manusia. Varia Peradilan Nomor 335 Oktober 2013. hal 90
} 
Apabila berlaku kekerasan dalam rumah tangga dalam keluarga, negara juga menunjukkan peranannya dalam menangani tindak pidana melalui saluran hukum pidana dan saluran di luar hukum pidana, yang dilaksanakan secara bersepadu. ${ }^{46}$

Saluran melalui proses kehakiman bermaksud saluran terhadap tindak pidana kekerasan dalam rumah tangga yang dialami korban boleh diproses atau diselesaikan dengan mekanisme kehakiman dengan tujuan memperbaiki pelaku agar menjadi orang yang lebih baik, memberikan pembalasan terhadap pelaku agar merasa penghalang untuk tidak mengulangi perbuatannya, serta mencegah pelaku menjadi lebih berpotensi dalam melakukan tindak pidana kekerasan dalam rumah tangga. Mekanisme kehakiman yang dimaksudkan adalah mekanisme melalui sistem keadilan tindak pidana. Negara telah mempunyai lex generalis bagi tindak pidana ini yaitu Kitab Hukum Hukum Pidana dan lex specialis yaitu Undang Undang Nomor 23 Tahun 2004 tentang Penghapusan Kekerasan Dalam Rumah Tangga. Mekanisme sistem keadilan tindak pidana mempunyai konsep perlindungan hak-hak asasi manusia, bukan hanya dianggap sebagai untuk menindas pelaku, tetapi lebih mementingkan kasususilaan dan kegunaan perundangan tindak pidana sehingga meletakkan pelaku dan korban secara utuh dalam proses kehakiman. ${ }^{47}$

Adanya lex specialis yaitu Undang Undang Nomor 23 Tahun 2004 tentang Penghapusan Kekerasan Dalam Rumah Tangga, menandakan bahwa telah berlaku pindaan peraturan hukum dari hukum persendirian menjadi hukum awam dan juga adanya pindaan anjakan paradigma pemikiran masyarakat untuk mencegah dan menanggulangi kekerasan dalam rumah tangga yang terus bertambah terhad kekerasan fisik suami terhadap istri sehingga memerlukan hukum yang jelas dan perundangan tindak pidana kepada pelaku secara adil. ${ }^{48}$

Undang Undang Nomor 23 Tahun 2004 mengatur permasalahan kekerasan dalam rumah tangga dengan lebih khusus yang mengandungi unsur pembetulan, pencegahan dan perlindungan. Unsur pembetulan terhadap pelaku, Undang Undang Nomor 23 Tahun 2004 mengatur alternatif sekatan daripada hukum pidana berupa kerja sosial dan program campur tangan yang dikuatkuasakan tehadap pelaku. Hal ini dimaksudkan agar pelaku tidak kembali melakukan tindakan kekerasan.

\footnotetext{
Diponegoro. hal 4

${ }^{47}$ Yesmil Anwar, Adang. 2009. Sistem keadilan tindak pidana. Bandung. Widya. hal 43

48 Anny Retnowaty. 2013. Fungsionalisasi Undang Undang Nomor 23 Tahun 2004. Jurnal Hukum Ius Quia Iustum Nomor 1 Nomor 20 Januari 2013. hal 142-159
}

46 Barda Nawawi Arief. 1996. Bunga Rampai Bidangkuasa Hukum pidana . Semarang. Universitas 
Unsur pencegahan terhadap masyarakat, Undang Undang Nomor 23 Tahun 2004 pula bertujuan untuk mencegah tindakan kekerasan yang berlaku dalam lingkup rumah tangga, karena selama ini masalah kekerasan dalam rumah tangga dianggap masalah persendirian sehingga kekerasan yang berlaku tidak mudah untuk dicampur tangan.

Unsur perlindungan terhadap korban, Undang Undang Nomor 23 Tahun 2004 mengandungi perlindungan terhadap korban kekerasan yang berlaku dalam hubungan domestik, khususnya terhadap pihak bawahan (Kumpulan terdedah yaitu: wanita dan anakanak).

Pertembungan paradigma ini disebabkan oleh peraturan mengenai kekerasan dalam rumah tangga dalam Kitab Hukum Hukum Pidana belum memberikan perlindungan yang mencukupi kepada korban. Ini karena Kitab Hukum Hukum Pidana hanya mengatur kekerasan fisik saja dengan kriteria yang telah dinyatakan dalam Pasal 89 dan Pasal 90 yaitu luka berat, tidak mampu menjalankan tugas jabatan, kehilangan salah satu pancaindera, lumpuh dan gangguan daya fikir. Sedangkan kekerasan lain yang dialami oleh korban kekerasan dalam rumah tangga tidak boleh disentuh oleh Kitab Hukum Hukum Pidana karena hukum tersebut tidak mengandungi hukuman untuk tindak pidana dengan tempoh yang paling singkat dan perundangan tindak pidana yang dijatuhkan tidak dapat memenuhi keadilan kepada korban serta perundangan yang dijatuhkan menurut Pasal 351 maksimumnya lima tahun dan ditambah sepertiganya hukuman Pasal 356.

Realiti di lapangan, pelaku dijatuhi perundangan dengan tindak pidana sangat rendah atau percobaan bergantung pada persepsi pendakwa sebagai pendakwa atau hakim sebagai kehakiman dalam sistem penegakan hukum dan korban dianggap sebagai saksi dan penyokong pembuktian, sama seperti kasus penganiayaan biasa berlaku di masyarakat. ${ }^{49}$

Bermula dengan proses pelaporan korban / kuasa korban terhadap kasus kekerasan dalam rumah tangga diterima oleh Unit Perkhidmatan Wanita dan Anak, Polisi akan menyiasat, memeriksa dan melengkapkan fail sebelum diserahkan kepada Penuntut Umum. Selanjutnya jika Penuntut Umum berpendapat fail telah lengkap dan cukup bukti maka fail diserahkankan ke Pengadilan Negeri sesuai dengan ketentuan Kitab Hukum Hukum Acara Pidana. Sementara itu, Majelis Hakim pada awal persidangan menganjurkan melakukan pengantaraan penal untuk menyelesaikan kasus kekerasan dalam rumah tangga dengan pengantara yang ditentukan oleh para pihak atau ketua majlis. Apabila

\footnotetext{
${ }^{49}$ Rita Saraswati. 1995. Wanita dan Penyelesaian Kekerasan Dalam Rumah Tangga. Bandung. Citra Aditya Bandung. hal 225-226
} 
pengantaraan penal berjaya pada titik damai, maka para pihak menandatangani perjanjian perdamaian, dan jika sebaliknya pengantaraan penal tidak berjaya mencapai kespakatan damai, maka perbicaraan dilanjutkan sesuai dengan Kitab Hukum Hukum Pidana dan Undang Undang Nomor 23 Tahun 2004 tentang Penghapusan Kekerasan Dalam Rumah Tangga.

Dengan kata lain bahwa saluran melalui proses kehakiman menitikberatkan sifat pencegahan selepas berlakunya tindak pidana. Sementara saluran tidak melalui proses kehakiman lebih mendekatkan pada sifat pencegahan sebelum tindak pidana berlaku. ${ }^{50}$ Cara hukum dan bukan hukum dalam mengatasi masalah tindak pidana diperlukan supaya adanya kesimbangan. Ini karena cara penal mempunyai kelemahan antaranya ialah kepentingan peribadi atau golongan, kurang memerhatikan kerugian korban, perlunya kos tinggi dan infrastruktur yang cukup sehingga boleh menjadi penghalang dalam usaha pencegahan pada tahap amalan dan pelaksanaan terhadap suspek. ${ }^{51}$

Usaha kebijakan kehakiman dalam rangka memberikan perlindungan kepada korban boleh dilakukan dengan cara penegakan hukum terhadap peraturan yang dilanggar. Tujuannya agar pelaku mendapatkan perundangan yang setimpal dengan perbuatannya dan merasa penghalang kepada perbuatan tersebut sehingga tidak akan mengulanginya kembali kepada korban ataupun masyarakat lain. Undang Undang Nomor 23 Tahun 2004 tentang Penghapusan Kekerasan Dalam Rumah Tangga adalah sebuah sistem hukum yang memberikan perlindungan negara terhadap warganegara. Sedangkan usaha non penal dimaksudkan bahwa penegakan hukum tidak perlu selalu menggunakan hukum pidana, namun adanya usaha-usaha non penal merupakan pencegahan sebelum kekerasan fisik terhadap istri yang dilakukan suami melalui faktor punca berlakunya kekerasan tersebut baik langsung atau tidak langsung. ${ }^{52}$

Saluran tidak melalui proses kehakiman terhadap tindak pidana kekerasan dalam rumah tangga dilakukan oleh negara berupa dasar sosial ekonomi yang dapat mengurangkan tekanan sosial dan ekonomi dalam masyarakat khususnya keluarga, pendidikan, kaunseling dan sosialisasi norma.

Tindakan yang dilakukan oleh negara dalam memberikan perlindungan hukum terhadap korban dan penegakan hukum terhadap pelaku serta masyarakat adalah supaya

${ }^{50}$ Siswantoro Sunarso. 2004. Penegakan Hukum Psikotropika Dalam Kajian Sosiologi Hukum. Jakarta. Rajawali Pers. hal 15

51 Barda Nawawi Arief. 2010. Masalah Penegakan Hukum dan Bidang kuasa Hukum pidana Dalam Pencegahan Tindak pidana. Jakarta. Kencana Prenada Media Group. hal 79

${ }^{52}$ Siswantoro Sunarso. Opcit hal 15 
tidak menimbulkan korban berganda dari suatu tindak pidana kekerasan dalam rumah tangga. 53

Hukum pidana yang disenaraikan dalam Kitab Hukum Hukum Pidana dan Undang Undang Nomor 23 Tahun 2004 tentang Penghapusan Kekerasan Dalam Rumah Tangga bukanlah matlamat utama dalam penegakan hukum oleh negara untuk pelaku tindak pidana, ${ }^{54}$ tetapi merupakan cara agar pelaku kekerasan dalam rumah tangga tidak mengulangi kembali dan mengubah tingkah laku menjadi lebih baik dan bertanggungjawab terhadap keluarganya. Hal ini juga berlaku di negara lain seperti Malaysia, bahwa keperluan akan akta mengenai kekerasan dalam rumah tangga sangat diperlukan untuk memberi pertolongan kepada orang awam dan pertolongan kepada korban yang mengalami kekerasan dalam rumah tangga. Adapun yang melindungi wanita dari tindak pidana kekerasan dalam rumah tangga adalah Kanun Kesksaan Akta 574, Akta Kekerasan dalam rumah tangga 1994 Akta 521 yang telah dipinda dengan Akta Kekerasan dalam rumah tangga (Pindaan) 2012 yang dipakai untuk seluruh Malaysia.

Wanita (istri) yang mengalami kekerasan dalam rumah tangga yang dilindungi daripada pelaku (suami) kekerasan dalam rumah tangga adalah suami istri yang telah berkahwin dengan perkawinan yang mengikuti Syariah atau adat yang berkenaan baik perkawinan itu didaftarkan atau tidak dalam Undang Undang tertulis

Dalam proses pencegahan dan tindakan balas bagi menangani kekerasan dalam rumah tangga, melalui Undang Undang Nomor 23 Tahun 2004 sebagai lex specialis, maka kerajaan, selain perundangan tindak pidana kepada pelaku, juga menyenaraikan peranan agensi penegakan hukum, agensi/institusi yang ada dalam masyarakat untuk memberikan perkhidmatan terhadap korban kekerasan dalam rumah tangga. Badan/institusi yang bertanggungjawab dalam memberi perkhidmatan kepada korban kekerasan dalam rumah tangga dapat diuraikan sebagai berikut:

\section{Peranan Polisi}

Peranan Polisi dalam memberikan perkhidmatan kepada korban kekerasan dalam rumah tangga dan memenuhi haknya dapat dilihat peraturannya dalam Pasal 16 sehingga Pasal 20 Undang Undang Nomor 23 Tahun 2004 tentang Penghapusan Kekerasan Dalam

53 Christine Littleton, “Woman's Experience and the Problem of Transition : Perspectives on Male Battering Woman, dalam Weisberg. D. Kelly. 1996. Application of Feminist Legal Theory to Woman's Lives: Sex, Violence, Work and Reproduction. Temple University Press. hal 328

${ }^{54}$ Roeslan Saleh. Opcit. hal 9 
Rumah Tangga. Bagi kekerasan dalam rumah tangga dari korban ataupun keluarga korban atau dari masyarakat, mereka perlu segera menerangkan hak korban untuk mendapatkan perkhidmatan dan pendampingan seperti yang termaktub dalam Pasal 18 yang menyebutkan: "Polisi wajib memberikan keterangan kepada korban tentang hak-hak korban untuk mendapatkan perkhidmatan dan pendampingan,"

Memberikan keterangan kepada korban tentang haknya mendapatkan perkhidmatan dan pendampingan sangat penting ertinya kepada korban karena korban kekerasan dalam rumah tangga boleh mengalami stres atau penderitaan fisik berupa lukaluka atau lain-lain sehingga dapat mengganggu tumpuan atau pemikiran korban dalam melaporkan dan menceritakan peristiwa kekerasan yang dialaminya. Jika haknya terhadap pelayanan dan pendampingan pada setiap tahap proses penyiasatan dan kehakiman dipenuhi, maka korban diyakini boleh menceritakan dan memberikan keterangan tentang peristiwa yang dialaminya dengan lancar dan tidak berada di bawah tekanan karena merasa yakin ada yang akan mendampingi dan melindunginya.

Selain itu, Polisi perlu memperkenalkan identiti mereka serta menegaskan bahwa kekerasan dalam rumah tangga adalah sebuah tindak pidana terhadap kemanusiaan. Ini diperlukan agar korban kekerasan dalam rumah tangga mengetahui bahwa pada masa tersebut dia sedang berhadapan dengan penguasa penegak hukum yang akan melindunginya. Dengan mengetahui bahwa peristiwa kekerasan yang dialaminya merupakan tindak pidana terhadap martabat kemanusiaan, maka korban kekerasan tidak akan segan-segan dan tidak akan takut-takut dalam menceritakan kekerasan yang menimpanya, walaupun sebenarnya yang melakukan kekerasan itu adalah orang yang berada dalam lingkup rumah tangganya sendiri.

Selepas menerima kasus dan laporan, Polisi perlu mengambil langkah-langkah seperti berikut: Memberikan perlindungan sementara kepada korban, meminta surat penetapan perintah perlindungan dari pengadilan dan melakukan siasatan. Kewajiban Polisi untuk segera memberikan perlindungan sementara kepada korban kekerasan dalam rumah tangga dilaksanakan dalam jangka waktu 24 jam dan perlindungan sementara ini dapat diberikan selama 7 (tujuh) hari sejak korban diterima atau ditangani. Dalam memberikan perlindungan sementara kepada korban, Polisi dapat bekerjasama dengan pihak lain atau sukarelawan. Maka Polisi wajib melakukan siasatan terhadap kasus tersebut. 
Polisi diwajibkan segera menyiasat kasus tersebut tanpa perlu menunggu lagi pengaduan atau laporan daripada korban ataupun keluarga korban atau orang lain. Langkah demikian perlu dilaksanakan oleh Polisi untuk memberikan perlindungan terhadap korban kekerasan dalam rumah tangga dan hak-hak yang bersangkutan dengannya.

\section{Peranan Pengacara}

Pengacara adalah orang yang selalu mendampingi korban baik di peringkat penyiasatan sehingga tahap proses kehakiman di Pengadilan Negeri. Pengacara memegang peranan penting dalam hal pendampingan korban. Jika kewajiban Pengacara adalah untuk mendampingi korban, maka pendampingan dari Pengacara sudah menjadi hak korban kekerasan dalam rumah tangga.

Kewajiban Pengacara dalam urusan memberikan perkhidmatan kepada korban kekerasan dalam rumah tangga ialah memberikan konsultasi hukum yang merangkumi pernyataan mengenai hak-hak korban dan proses kehakiman, mendampingi korban di peringkat penyiasatan, penuntutan, perbicaraan dalam sidang pengadilan dan membantu korban untuk secara lengkap memaparkan kekerasan dalam rumah tangga yang dialaminya, melakukan koordinasi bersama penguatkuasa hukum, sukarelawan pendamping dan pekerja sosial agar proses kehakiman berjalan sebagaimana yang seharusnya. Kewajiban Pengacara sangat penting supaya terlaksananya proses penegakan hukum pada kasus kekerasan dalam rumah tangga, terutama pada pendampingan korban.

\section{3 . Peranan Penuntut Umum}

Adalah menjadi kewajiban Penuntut Umum memberikan perlindungan kepada korban kekerasan dalam rumah tangga. Namun demikian, peranan Penuntut Umum dalam memberikan perlindungan kepada korban kekerasan dalam rumah tangga dapat dilihat dari tugas Penuntut Umum dalam rangka penegakan hukum terhadap tindak pidana. Dalam konteks, Penuntut Umum dapat memberikan perlindungan kepada korban kekerasan dalam rumah tangga dengan menuntut pelaku tindak pidana tersebut sesuai perundangan yang termaktub dalam Pasal-Pasal yang dilanggarnya dalam Undang Undang Nomor 23 Tahun 2004 tentang Penghapusan Kekerasan Dalam Rumah Tangga, yaitu pada Bab VIII mulai Pasal 44 hingga Pasal 50.

Penuntut Umum dapat melakukan pendakwaan terhadap pelaku tindak pidana kekerasan dalam rumah tangga sesuai perbuatan yang dilakukannya, di mana pada hukum 
ini termaktub tuntutan tindak pidana maksimum boleh dituntut 15 tahun dan tuntutan denda paling tinggi sebesar Rp. 500.000.000, (lima ratus juta rupiah).

\section{Peranan Pengadilan}

Peranan pengadilan dalam melaksanakan tanggungjawabnya memberikan perlindungan kepada korban kekerasan dalam rumah tangga lebih dititikberatkan dalam pelaksanaan mekanisme perintah perlindungan. Atas permohonan surat penetapan perintah perlindungan kepada korban kekerasan dalam rumah tangga dari Polisi, maka pengadilan perlu mengeluarkan surat penetapan yang berisi perintah perlindungan kepada korban dan ahli keluarga lain. Atas permohonan korban atau kuasanya, pengadilan dapat mempertimbangkan untuk menetapkan suatu keadaan khusus yaitu perintah sekatan kepada pelaku, larangan memasuki tempat tinggal bersama, larangan mengekori, mengawasi dan mengugut korban.

Apabila berlaku pelanggaran terhadap perintah perlindungan, maka korban boleh melaporkan kepada Polisi, kemudian secara bersama dapat menyusun laporan yang dirujukkan kepada pengadilan. Selepas itu pengadilan wajib memanggil pelaku untuk mengadakan siasatan dan meminta pelaku untuk membuat kenyataan bertulis yang isinya berupa kesanggupan untuk mematuhi perintah perlindungan. Apabila pelaku masih melanggar surat pernyataan itu, maka pengadilan boleh menahan pelaku sehingga 30 (tiga puluh) hari lamanya.

\section{Peranan Pendamping Kesehatan}

Bagi perkhidmatan kesehatan kepada korban, kakitangan kesehatan perlu memeriksa kesehatan korban mengikut standard profesionalnya, membuat laporan tertulis hasil perbicaraan terhadap korban dan 'visum et repertum' atas permintaan penyiasat Polisi atau surat keterangan perobatan yang mempunyai kekuatan hukum yang sama sebagai alat bukti. Perbicaraan kesehatan dan kewajiban tenaga kesehatan dalam hal memberikan perkhidmatan kesehatan kepada korban kekerasan dalam rumah tangga sangat penting ertinya dan dapat dijadikan sebagai alat bukti untuk proses penegakan hukum kekerasan dalam rumah tangga.

\section{Peranan Pekerja Sosial}


Peranan pekerja sosial pula ialah untuk melakukan kaunseling bagi menguatkan dan memberikan rasa aman kepada korban, memberikan pernyataan mengenai hak-hak korban untuk mendapatkan perlindungan dari Polisi dan penetapan perintah perlindungan dari pengadilan, menghantar korban ke rumah perlindungan atau tempat tinggal alternatif dan melakukan koordinasi yang bersepadu dalam memberikan perkhidmatan kepada korban dengan pihak Polisi, badan perkhidmatan sosial, institusi sosial dan agensi-agensi perlindungan yang diperlukan korban.

Kehadiran pekerja sosial dalam pemberian khidmat kepada korban kekerasan dalam rumah tangga sangat diperlukan oleh korban, terutama dalam memberikan kaunseling atau bimbingan kepada korban. Bimbingan yang diberikan pekerja sosial boleh berbentuk dorongan semangat kepada korban agar korban tidak stres atau mengalami tekanan batin selepas mengalami peristiwa kekerasan yang dilakukan oleh ahli keluarga atau ahli rumah tangga di mana korban menetap.

Seorang korban kekerasan dalam rumah tangga diyakini tidak mengetahui hakhaknya sebagai korban, sehingga pekerja sosial diharapkan dapat memberikan penerangan terhadap hak korban. Pekerja sosial boleh menyelaras dengan agensi-agensi lain yang berkaitan dalam hal perlindungan korban. Pendampingan oleh pekerja sosial terhadap korban kekerasan dalam rumah tangga dapat dilakukan pekerja sosial di rumah perlindungan baik milik kerajaan, majlis daerah ataupun milik masyarakat.

\section{Peranan Sukarelawan Pendamping}

Tugas sukarelawan pendamping dalam pemberian perkhidmatan kepada korban kekerasan dalam rumah berupa memaklumkan korban akan haknya untuk mendapatkan seorang atau beberapa orang pengiring bagi mendampingi korban di peringkat penyiasatan, penuntutan atau peringkat perbicaraan pengadilan. Mereka ini dapat membimbing korban secara objektif dan menyeluruh memaparkan kekerasan dalam rumah tangga yang dialaminya, mendengar secara empati segala pertuturan korban sehingga korban merasa aman dan memberikan dengan aktif pengukuhan secara psikologi dan fisik kepada korban.

Kewajiban sukarelawan pendamping dalam memberikan perkhidmatan kepada korban kekerasan dalam rumah tangga hampir sama dengan kewajiban pekerja sosial. Sukarelawan pendamping boleh terdiri daripada pertubuhan bukan kerajaan ataupun dari pihak lain yang bersimpati dengan korban melalui meluangkan waktunya secara sukarela untuk melakukan pendampingan kepada korban dan memberi bantuannya kepada korban 
berkaitan keperluan korban kekerasan dalam rumah tangga terhadap pemenuhan hakhaknya.

8. Peranan Pembimbing Rohani.

Tugas pembimbing rohani dalam memberi perkhidmatan kepada korban kekerasan dalam rumah tangga perlu berupa memberi penjelasan mengenai hak, kewajiban dan memberi penguatan iman dan takwa kepada korban. Pembimbing rohani diberikan tugas untuk membimbing keimanan dan ketakwaan korban sesuai kepercayaannya, dan memberitahu tentang hak korban. Pembimbing rohani yang memberikan perkhidmatan berupa pengajaran keagamaan kepada korban bersesuaian dengan agama dan kepercayaan yang dianuti korban dapat mengembalikan rasa kepercayaan dan meningkatkan keimanan korban kepada Tuhan Yang Maha Esa. Di samping itu korban akan mendapatkan pelajaran bagaimana ajaran berkeluarga menurut agama yang dianutnya.

\section{E. Daftar Pustaka}

Talcott Parson, Robert F. 1955. Socialization and Interaction Process. Gleneoe. The Free Press.

E. Kristi Poerwandari. Pemahaman Bentuk Kekerasan Terhadap Wanita dan Alternatif Pemecahannya. Jakarta. Pusat Kajian Wanita dan Jender. Universitas Indonesia, 2000.

M. Lemert.. Kajian Kritis dan Analitis Terhadap Dimensi Teori - Teori Kriminologi Dalam Persfektif Ilmu Pengetahuan Hukum pidana Modern Ed Lilik Mulyadi. PN Kepanjen. Malang. 2009.

Muladi Dan Barda Nawawi Arief. Teori - Teori dan Bidang kuasa Tindak pidana, Bidangkuasa Pencegahan Tindak pidana dengan Undang - Undang Tindak pidana. Bandung . Alumni. 1992.

Guse Prayudi. Berbagai Aspek Tindak pidana Kekerasan Dalam Rumah Tangga. Merkid Press. Yogyakarta. 2011

Moerti Hadiati Soeroso. Kekerasan Dalam Rumah Tangga Dalam Perspektif Perundangan-Viktimologis. Sinar Grafika . Jakarta. 2010.

Core Group. Modul Konseling kepada Pelaku Kekerasan Dalam Rumah Tangga. Mitra Wanita Workshop. Jakarta. 2008.

Muhammad Mustafa. Kriminologi. Bina Aksara. Jakarta. 1986.

Stephan Hurwitz. Kriminologi. Ed. Moeljatno. Bina Aksara. Jakarta. 1986.

Mardjono Reksodiputro. Hak Asasi Manusia Dalam Sistem keadilan tindak pidana Kumpulan Karangan Buku Ketiga. Universitas Indonesia. Jakarta, 2007. 